\title{
The Existence of Leadership Ascetism Value in the Babad Banyumas Wirjaatmadjan in Indonesia
}

\author{
Ali Ma'ruf \\ Fakultas_Keguruan dan Ilmu \\ Pendidikan \\ Universitas Sebelas Maret \\ Surakarta, Indonesia \\ Syarif Hidayatullah State \\ Islamic University Jakarta, \\ Indonesia \\ alimaruff23@gmail.com
}

\author{
Nunuk Suryani \\ Fakultas Keguruan dan Ilmu \\ Pendidikan \\ Universitas Sebelas Maret \\ Surakarta, Indonesia \\ Syarif Hidayatullah State Islamic \\ University Jakarta, Indonesia \\ nunuksuryanilstaff.fkip.uns.ac \\ .id
}

\author{
Hermanu Joebagio \\ Fakultas Keguruan dan Ilmu \\ Pendidikan \\ Universitas Sebelas Maret \\ Surakarta, Indonesia \\ Syarif Hidayatullah State Islamic \\ University Jakarta, Indonesia \\ hermanu.joebagio@gmail.com
}

\begin{abstract}
This research described the leadership ascetism value in the Babad Banyumas Wirjaatmadjan and its existence on leadership in the Banyumas in particular and in Indonesia in general nowadays. Babad Banyumas Wirjaatmadjan was one of the manuscripts of Banyumas society. Babad Banyumas Wirjaatmadjan contained the context of life values which reflected in the ancestors' story of Banyumas society. One of the values that could not be removed was the leadership value. The leadership in Babad Banyumas Wirjaatmadjan showed that there was a similarity of leadership style in several figures of Banyumas society. In several figures of Banyumas society, it was told that the leaders of Banyumas did asceticism to get certain purposes. This was surely contradictory with the asceticism value which basically removed mundane things. However, in the text of Babad Banyumas, it showed that asceticism was done by the former leaders of Banyumas society. The results of this research found that the leaders of Banyumas did asceticism to keep the power. Even, asceticism was done to keep the grandchildren's future in order to get the power. In this global era, the asceticism value of leadership in Babad Banyumas got many challenges. It could not be separated from the loss of asceticism and leadership value in the young generation of Banyumas society.
\end{abstract}

Keywords-Babad Banyumas Wirjaatmadjan; Leadership; Asceticism; Mesopotamia; Hermeneutic

\section{INTRODUCTION}

Leadership was an important thing in building and organizing a society. Society in the social life needed a figure that was capable to organize life in society. Leadership had to be able to eliminate, reduce and negate various kinds of individual activities and try to lead, direct and guide numbers of people to do a similar activity [1]. It was found the differences of individual's attitude in a society. The differences would cause chaos in society if they were not addressed properly. The differences between individuals could be addressed well if society had a figure that was capable to organize the people.

Leadership in Indonesian society could be stated in crisis in last several decades. The problems of leadership had begun since the New Order government if they were studied more. The New Order government built their legitimacy of the government in the stereotype of hierarchy and harmony [2]. It was done by obeying every leader in a village who was considered as the long hands of the government. The impact for society was the emergence of fear of society to the leader during New Order era. This condition was getting worse with the deviation of authority done by officials until now.

The power and leadership could not be separated from both these related things. Power was a tool used by a leader in influencing other people. Burns explained that power was not something used to other people to get their own purposes, but power happens in the relationship among humans [3]. A power for a leader should be run well because it relates to a leader's responsibility. The values of leadership are important to be owned by every leader to organize the society. Relating to this research, the researcher tries to explain the values of leadership in the text of Babad Banyumas Wirjaatmadjan.

Babad Banyumas Wirjaatmadjan was a manuscript from the ancestor of Banyumas society. The values of leadership in Babad Banyumas Wirjaatmadjan could be known through the content of Babad which told some Banyumas leaders who did asceticism. In Islamic teaching, asceticism was called as zuhd which was born as the reaction to the luxurious life of caliph and the family as well as the

state officials as the results of the wealth got after Islam spreads to Syria, Egypt, Mesopotamia and Persia [4]. Asceticism was an action which left the temporary happiness of the world. An ascetic did hermitage or surrender to the sovereign of the universe. The leadership of asceticism was found in Indonesian society present. This was reflected in officials 'behavior which lived in luxury with the state's facilities. The official or leader who was the representation of people was caught in legal case due to the deviation of authority.

\section{METHOD}

This research focused on the leadership value of asceticism in Babad Banyumas Wirjaatmadjan. This research used the qualitative research method with Gadamer hermeneutic approach. Qualitative research method was often called as the method of naturalistic research because the research was conducted in natural setting; also called as ethnography 
method, because previously this method was often used for research in the field of cultural anthropology; called as the qualitative method because the data collected and the analysis were qualitative [5]. The data collection was done through observation, the collection of book resources and another article as well as interviews with some figures. The informant determination was done through criteria which were appropriate with the focus of research, so that the research was emphasized on the relevance of asceticism leadership in Babad Banyumas Wirjaatmadjan with the present life.

This research tried to find the meaning both the meaning behind a word, sentence and literary works because the main characteristic of the qualitative method in post- positivism paradigm was found the meaning behind data [6]. To reveal the meaning behind the words and Semiotic Approache was required in this research. One of the famous figures in this hermeneutic approaches was Hans-George Gadamer. According to Gadamer hermeneutic approaches not just on the question of the methodology of interpretation, but the interpretation was an ontology, namely that understanding itself was the way of being of man [7]. In this case according to Gadamer, truth that will be achieved not through a method but through many questions and then created a dialectic. The dialectic according to Gadamer was not a methodology. The method according to him was not the way to the find to the truth. The truth, he said, was obtained not through methods but through the dialectical [8].

The result of qualitative research was to produce meaningful information. The result was beneficial to help to solve the problems which were faced now and in the future. The relevance of this research tried to solve the problems related to the leadership which was fewer leaders having ascetic behavior. The leadership existence of ascetic in Babad Banyumas Wirjaatmadjan got challenges today. Therefore, this research tried to describe the existence leadership of ascetics through the values of ascetics in Babad Banyumas Wirjaatmadjan in life today.

\section{RESUlt AND DISCUSSION}

\section{A. Asceticism}

Asceticism in brief meaning could be interpreted as holding the passion to mundane things. Asceticism which comes from English "asceticism" means a lesson to live according to the will of God through hermitage [9]. Asceticism was the reversal of body flow which attempts to reverse the flow of time. In this case, the shape of asceticism is by doing hermitage of asceticism which refers to the habit of the body ruled to limit the instinctive impulse of the body. Someone who does asceticism has a view that by doing a good thing, they can get happiness for their selves.

Asceticism was a way where a tradition appreciates body or force order upon it, in the sense that body was subjected to institutional power, but in the eremite body also exceeds the institutional power [10]. The hermitage, in this case, means that it has a purpose to calm the self from mortal or mundane things. Eremite basically must adopt the traditional values with the self's narration for various reasons.
Asceticism was closely related to the tradition in its limitation. In this case, the subjectivity of ascetic constructed by an eremite was collective subjectivity because it was closely related to the tradition of memory. The tradition has a complex character because it relates to the human behavior in the past. This is closely related to the collective memory in society from generation to generation. The memory is formed through tradition which is reconstructed in shared imagination. The tradition presents the representation of the body, theoretical and practical intelligence; behavior, attitude, and so on which are accepted by a group of society in the name of the community which was needed between past and present [10]. With a tradition of things that come on the experience, they can understand the meaning of a text. The meaning of the text is a part of the flow of these experiences and the history of where we are [8].

The tradition of the ascetic was formed in language and body through a discourse. The tradition of asceticism was formed through a broader framework of collective memory. A broader tradition could form asceticism as the main discourse. In general, the tradition of ascetic has three characteristics. The first was that there was a tradition of religious cosmology in an eremite. The second was that it always emphasizes the interiority which aims to emphasize the hierarchy by exceeding what he has got in the tradition of cosmology. The third was that ascetic was a memory of a tradition in a society which develops time to time.

\section{B. Asceticism Leadership in Babad Banyumas Wirjaatmadjan}

Babad was one of literature heritage that has value behind the contents and the writing. Most of writing babad was based on oral narrative or oral source from some generations. Oral literature tendency had a simple form with stereotype models so it was easy to remember and to be delivered to public [11]. The oral tradition of literature writing in Indonesian community could be found in some regions in Java. For example, Oral tradition Banyumas Community that was written in Babad Banyumas Wirjaatmadjan.

Babad Banyumas Wirjaatmadjan contains 69 pages that pages 1-39 has been written by Patih Wiraatmadja, while pages 40-69 was continued by Patih Poerwasopradja. Babad Banyumas Wirjaatmadjan described about the heads of Banyumas Community from Majapahit Era until Colonial. Babad Banyumas Wirjaatmadjan started from Majapahit era in term government of Brawijaya V. Babad Banyumas Wirjaatmadjan told that the first ancestors Banyumas was Raden Baribin who was the younger brother of Brawijaya V. Raden Baribin told that was leaving Majapahit when he was hunted by kingdom knights because considered would be seized Brawijaya V Power.

Raden Baribin in avoiding Majapahit knights found a lot of obstacles because the sincere for leaving Majapahit in order to become an independent person. Independence in this matter was for itself by leaving the luxury of the kingdom. Raden Baribin chose to leave the kingdom in order to preserve the unity of the kingdom by choosing to become a hermit. 
Salvation Baribin who finally escaped and entered another country became the beginning of glory for his descendants in the area of Banyumas as the boundary of two kingdoms [12]. The two kingdoms referred to in this regard are the Kingdom of Majapahit and the Kingdom of Pajajaran. Raden Baribin gained independence in Sunda, who later became the leader in the power of Majapahit and Pajajaran.

Asceticism in Babad Banyumas Wirjatmadjan then reflected the founder of Banyumas, he was Jaka Kaiman. In Babad Banyumas it was reported that the Sultan of Pajang ordered the assassination of Wirasaba (a region to the north of Banyumas territory), named Wargautama [13]. The murder of Adipati Wargautama 1 occurred after a misunderstanding of the Sultan Pajang in response to the princess of Adipati Wargautama who was handed over to become the sultan's concubine.

Sultan Pajang was angry to listen that the ex-husband of Adipati Wargautama confessed still to become his wife. The information immediately made him angry and sent troops to kill child of Adipati Wargautama who had left kesultanan. After listening to the explanation to princess Duke, Sultan Pajang regretted his decision. In this case he asserted that the king's position in the Javanese society was considered to be a manifestation of the kingdom itself, becoming the country as it was [2]. Opposing a king means the same as opposing a proper kingdom for punishment.

Jaka Kaiman appointed to be substitute father-in- law to Adipati Wirasaba with Adipati Wargautama II, lifted of Jaka Kaiman as Adipati Wirasaba became the first way of the Banyumas forming. Jaka Kaiman realized with his position not as line of Adipati Wirasaba. For avoiding the discord of family, it was taken to share Wirasaba regions to all of Adipati Wargautama's I Sons. This was told in Babad Banyumas Wirjaatmadjan in page 8 that stated as follows :

"Sadoemoeginipoen ing Wirasaba ladjeng kagijaraken dateng para santana saha para loeloerah. Ing ngrikoe ki Dipati Wargaoetama II kagoengan palimarma dateng para saderek poetra tatilaranipoen $k i$ Dipati Wargaoetama I, inggih poenika: djajahan Wirasaba Kaperang dados sekawan, pijambakipoen ingkang madanani, para santana oetawi loeloerah oegi sami moepakat saha bingang (mila ki Dipati Wargaoetama II poenika doemoegi samangke katelahing nama Adipati Marapat). Para oetoesan ladjeng sami wangsoel dateng Padjang, poenapa kawontenipoen ing Wirasaba oegi kondjoek ing Kandjeng Soeltan sadaja".

Translation:
"Upon arrival at Wirasaba, the appointment was announced to the whole family. Adipati Wargautama II had a policy to his brother-in-law by dividing the wirasaba regions into four. He was the leader. The family and the lurahs agreed and rejoiced (thus, Adipati Wargautama II was now known as the Adipati Mrapat). The messengers went back to report to the Sultan what happened in Wirasaba".

\section{Asceticism Leadership in This Era}

Indonesian people suffered from failure in creating ascetic leader. In this modern era, it was difficult to create ascetic leader because there were many obstacles. It was caused by the globalisation progress which does not get good response from citizens. Citizens in this era had a tendency for hedonism or could be called as consumtive. The impacts in the community were very difficult to create a humble leader and not individualist. It was the worst because citizens who were not understanding the democratic in this globalisation era. Humans need a new ascetic elite and mystic to save them from the effects of democracy that degrade dignity [14]. Currently, Democracy in Indonesia was interpreted as a freedom in delivering opinions. Though freedom to deliver an opinion, of course, had its limitation to avoid the impacts.

In mode of modernity, human life was rationalized on a mechanical basis when asceticism was understood as an attempt to rebuild the world as a self-expression in life. The needs of the external world were guaranteed to increase the ultimate inevitability of the human power to achieve something which have not yet been achieved in the history life [15]. Asceticism in the modern world was seen as an act against Worlds matter such as ambition for power or economy. Ambition for power and not grateful made people doing various ways to get what they want.

Asceticism that tried to limit matters relating to the world was very precisely owned by a leader. Leaders who had an ascetic attitude would certainly pay more attention to the people compared with the personal interests. In Babad Banyumas Wirjaatmadjan, the ascetic attitude was reflected in Raden Baribin and Jaka Kaiman which were the ancestors of Banyumas society. The ascetic attitude of Raden Baribin and Jaka Kaiman actually made them and their descendants gaining prosperity despite living with simplicity. It was a reasonable example for Banyumas people to create leaders who were loved by their people because of their honors.

\section{CONCLUSION}

Indonesian society in globalization era was facing challenges in finding leaders who were concerned with the people than their personal interests. Nowadays, many leaders who were representatives of the people actually were caught in the corruption. Leadership required an attitude of asceticism to overcome hedonistic behavior in society because the values in ascetic that required a person to live humble and more concerned with the interests of others above personal interests. The attitude of asceticism could be emulated from the figures of Raden Baribin and Jaka Kaiman in Babad Banyumas Wirjaatmadjan.

Raden Baribin who in Babad Banyumas Wirjaatmadjan was described as an ancestor of Banyumas society exemplifies asceticism in his life. Raden Baribin wasted life and escape from the Majapahit kingdom face challenges until finally, he becomes an independent person in Sunda. While Jaka Kaiman was the first leader of Banyumas society. Jaka Kaiman taught the attitude of asceticism through his decision to share 
Wirasaba with his brothers. Jaka Kaiman realizes his existence as a Wirasaba leader was not a direct descendant of the previous leader. Therefore, Jaka Kaiman with his big-hearted attitude divides Wirasaba into four areas to prevent a power struggle. The attitude of asceticism was deservedly modeled for the leader of the present generation. This was to achieve a better life in the future both for Banyumas community in particular and Indonesian society.

\section{REFERENCES}

[1] Hadari Nawawi, Kepemimpinan Menurut Islam. Yogyakarta: Gadjah Mada University Press, 1993.

[2] Hans Antlov and Sven Cederroth, Kepemimpinan Jawa: Pemerintahan Halus, Pemerintahan Otoriter. Jakarta: Yayasan Obor Indonesia, 2001.

[3] Peter G. Northouse, Kepemimpinan: Teori dan Praktik, Edisi Keenam. Jakarta: Indeks, 2013.

[4] Asmaran, Pengantar Studi Tasawuf. Jakara: RajaGrafindo Persada, 2002.

[5] Sugiyono, Metode Penelitian Kuantitatif Kualitatif dan $R \& D$. Bandung: Alfabeta, 2009.

[6] Novia Wahyu Wardhani and I. Nurrochmat, "Revolusi Mental dalam Babad Alas Wanamarta” In. Jurnal Civics, vol. 13, no. 2, pp. 182-187, 2016.

[7] Sofyan, "Hermeneutika Gadamer dan Relevansinya dengan Tafsir" In Jurnal Farabi, vol. 11, no. 1, pp. 1- 16, 2014.

[8] Poespoprodjo, Interpretasi. Bandung: Remadja Karya, 1987.

[9] Fauzan, "Telaah Historis Munculnya Zuhud" In. Jurnal Darusalam, vol. 7, no. 2, pp. 1-14, 2008.

[10] Gavin Flood, The Ascetic Self Subjectivity, Memory and Tradition. New York: Cambridge University Press, 2004.

[11] Birsyada, Muhammad Iqbal, "Budaya Keraton Pada Babad Tanah Jawi dalam Perspektif Pedagogi Kritis” In. Jurnal Sejarah dan Budaya, vol. 10, no. 2, pp. 174- 185, 2016.

[12] Sugeng Priyadi, Sejarah Mentalitas Banyumas. Yogyakarta: Ombak, 2013.

[13] H.J. De Graaf and TH. Pigeaud, Kerajaan Islam Pertama di Jawa Tinjauan Sejarah Politik Abad XV dan XVI. Yogyakarta: Pustaka Pelajar, 1989.

[14] Anthony Black, Pemikiran Politik Islam Dari Masa Nabi Hingga Masa Kini. Jakarta: Serambi, 2006.

[15] Nurkhalis, "Positifikasi Asketisme Dalam Islam Dengan Pendekatan Paradigma Klasik dan Modern" In. Journal Substantia, vol. 16, no. 2, pp. 183-198, 2013. 